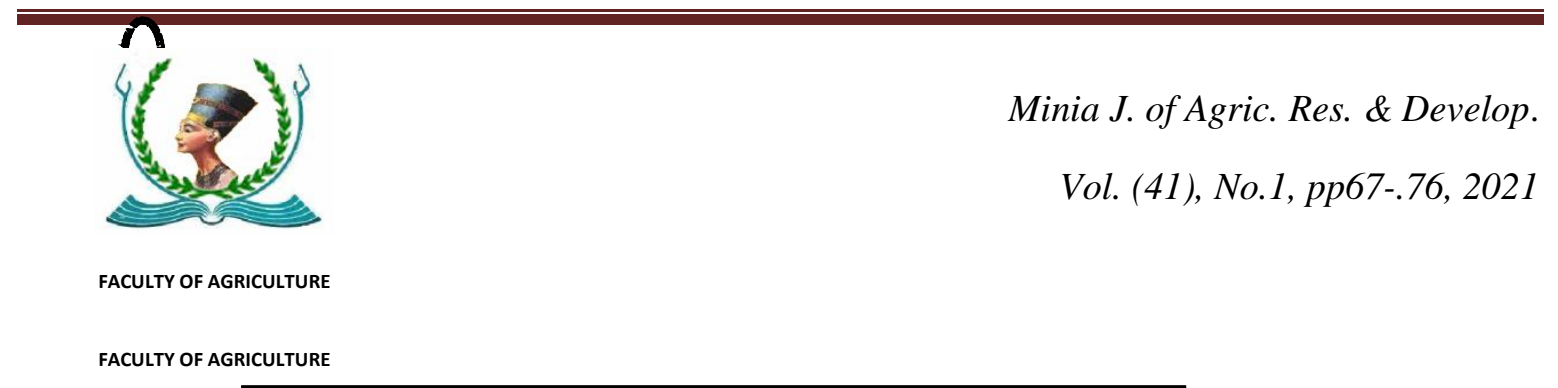

\title{
IMPACT OF SOME CLIMATIC FACTORS ON THE POPULATION DENSITY OF TWO RODENTS SPECIES AND THEIR ASSOCIATED ECTOPARASITES IN ANIMAL PRODUCTION FARM AT SHOSHA DISTRACT, MINIA GOVERNORATE.
}

\section{HASSAN, H. M.; ESHBAH, H. M.; KAMEL, E.H. EL ROBY, A.S.M.H.AND ABD EL-HAKEEM, A. A.}

\author{
Plant Protection Dept., Fac. of Agric., Minia Univ. \\ *Correspondence: E-mail:arwa.abdelhakem@mu.edu.eg
}

Received: 16July (2021) Accepted: 27September (2021)

\begin{abstract}
Redents and their ectoparasites populations are key components of animal production farms production in Egypt and all over the world. However, their population dynamics and the factors affecting their abundance are still not well understood. The seasonal variations during the activity periods of Rattus rattus frugivorous and Rattus norvegicus, and their associated ectoparasites with three weather factors i.e., maximum biweekly mean temperature, minimum biweekly mean temperature as well as biweekly mean relative humidity as significant drivers of the rodent and their associated ectoparasites presence were recorded. Results showed that the biweekly fluctuations of weather factors seem to be mostly a reaction wards condition in altering the activity of both the rodents and their associated ectoparasites. Both species had three periods of activity in the two years of study and four and five periods of activity of the ectoparasites on $R$. rattus frugivorous and $R$. norvegicus. The highest biweekly variation in rodent's population was observed on the date 12 March and 10th September for the two species respectively. Also, a significant positive and negative correlation between the climatic conditions and the population activity of the two rodents and their ectoparasites is dependent on the periods of the activity. The combined effect of the three weather factors on the fluctuation of population activity of the two species of rodents was ranged from 78.9 to $98.03 \%$ and from 55.31 to $99.11 \%$ for $R$. rattus frugivorous and $R$. norvegicus during the three periods of activity through the two years of study. The simultaneous effect of the three tested weather factors on the fluctuation of population activity of rodents and their ectoparasites were varied through periods of activity. The temperature and relative humidity were two key factors that influenced the seasonal fluctuation of rodents and ectoparasites.
\end{abstract}

Key words: Rattus rattus frugivorous, Rattus norvegicus, weather factors.

\section{INTRODUCTION}

Rodents represent over $40 \%$ of mammalian species in the world (Wilson and Reeder, 2005). They are characterized by high fluctuating population dynamics and metabolic rates (Krebs, 2013). They can reproduce several times per year, have high growth rates, and produce a lot of offspring; 
however, they act as human- and livestock-disease vectors (Taylor, 1972, Salit et al., 1982). Rodents cause economic losses in man food and often hinder production too, hamper health to people and livestock in villages. Rodents and their ectoparasites populations are an important component of many ecosystems around the world. Their population dynamics are important to the theoretical basis of population biology, ecology, and their control (Hegab et al, 2006). Their species can show three to six - years of population peaks (Krebs, 2013; Rizk et al., 2017). Little is known about the factors influencing the outbreak phenomena, such factors could include: weather conditions, population density, their overwintering success, food availability, and predator's prevalence (Radchuk et al., 2016 and Rizk et al., 2017). The high numbers population ("outbreaks") cause serious damage to crops, so requiring intensive and costly management efforts (Jacob and Tkadlec 2010). The most abundant and widely distributed species in Egypt's cultural landscape are Rattus rattus frugivorous and Rattus norvegicus.(El Roby,A.S.M. et al. (2021).

\section{MATERIALS AND METHODS}

Study area:

Data for this study were collected in an animal production farms in a newly reclaimed area at Shosha district, El.Minia Governorate, Egypt during two consecutive seasons (2017 and 2018). The study area had a variety of crop types: wheat, maize, mixed vegetables, as well as different fruit trees. The animal farm had also a variety of animal species: rabbits, sheep,cows, and buffalo, and many feed store.

\section{Trapping and environmental data}

We used biweekly trapping data from January 2017 to December 2018. Rodents wire-box traps with spring door $(25 \times 12 \times 10 \mathrm{~cm})$ were set biweekly and distributed at distances $5-10$ meters (Corominas, 2004; Nicolas and Colyn, 2006) as crow legs shape. We set traps baited with favorable food of rodents. Traps were distributed at night just before dusk and they checked the following morning for three days respectively. The number of set traps was 60 traps. For each captured rodents, the species was identified and recorded. Ectoparasites were collected from four captured rodent bodies were taken randomly on each date. The captured rodent bodies were dipped in bowl filled partially with liquid soap solution (water with few drops of detergent) to kill rodents by asphyxia and to remove the ectoparasites attached to the rodent bodies, then these ectoparasites were delivered to small jar contained $75 \%$ ethyl alcohol for identification aid of the stereoscopic microscope. The ectoparasites were classified as fleas, lice and mites. Identification of parasites was done according to keys constructed by (Karg 1971, Hughes, 1961 and 1976, Krantz,1978 and Evans,1992). One rodent represented one replicate. The average numbers of the detected animal organisms of four replicates were recorded and the general mean estimated and was recorded Relative humidity $\%$ and temperature data were collected from the climatic station of an airport, Minia governorate. And the average biweekly was calculated.

\section{Population dynamics of study:}

Population dynamics of the dominant rodents species and their ectoparasites were estimated during two years 2017\&2018. Aclose comparison was made between the rat curves and their ectoparasites and recorded climatic factors

(maximum biweekly mean temperature, minimum biweekly mean temperature as well as biweekly mean relative humidity), to indicate the confirmation between population activity and the climatic factors. These parts were subjected to simple correlation analysis to asses the separate of each climatic factor on population activity. 


\section{$\underline{\text { RESULTS AND DISCUSSION }}$}

The simultaneous effects of certain weather factors on the population densities of the two species of rodents:

Analysis of activity: -

A close comparison of the three figures running mean curves of the number of the two species of rodents and their ectoparasites with the corresponding curves of each of the three considered weather factors indicated that the activity of rodents and their ectoparasites confirmed to a great extent with the fluctuations of weather factors during certain periods in the considered season of study. It is obvious as shown in Fig 1 to 4 that these periods extended over three parts of the annual distribution curve of rodents. Certain parts of the annual distribution curve, represented by the number of rodents, are decidedly independent of those of weather factors. For more explanation, it could be concluded that certain parts of the annual curve are more influenced by the so-called " population effect". Therefore, these periods are independent weather factors. Such periods, in investigating the relationships between the number of rodents and certain weather factors, should be eliminated as far as possible (Rizk et. al., 1978). The prevailing biweekly mean relative humidity (X1) biweekly maximum temperature (X2), and biweekly minimum temperature (X3) were three considered variables tested in the present analysis for evaluating their real influence on the abundance of the two species of rodents and their ectoparasites. The separate effect of each weather factor on the number of rodents and ectoparasites was primarily carried out by calculating the simple correlation. More precise effects, however, were illustrated adopting partial regression termed the " C- Multipliers " on those factors. (Hosny, 1955).

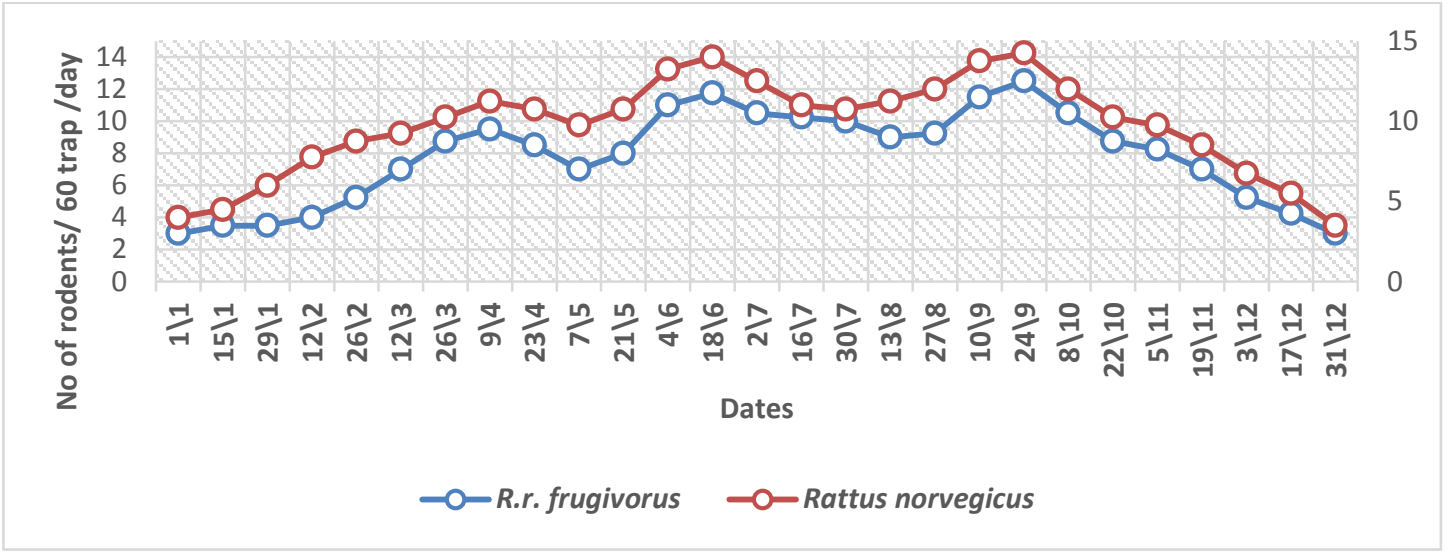

Fig (1): Population dynamic of rodents at Shosha animal production farm in samalote district during 2017. 


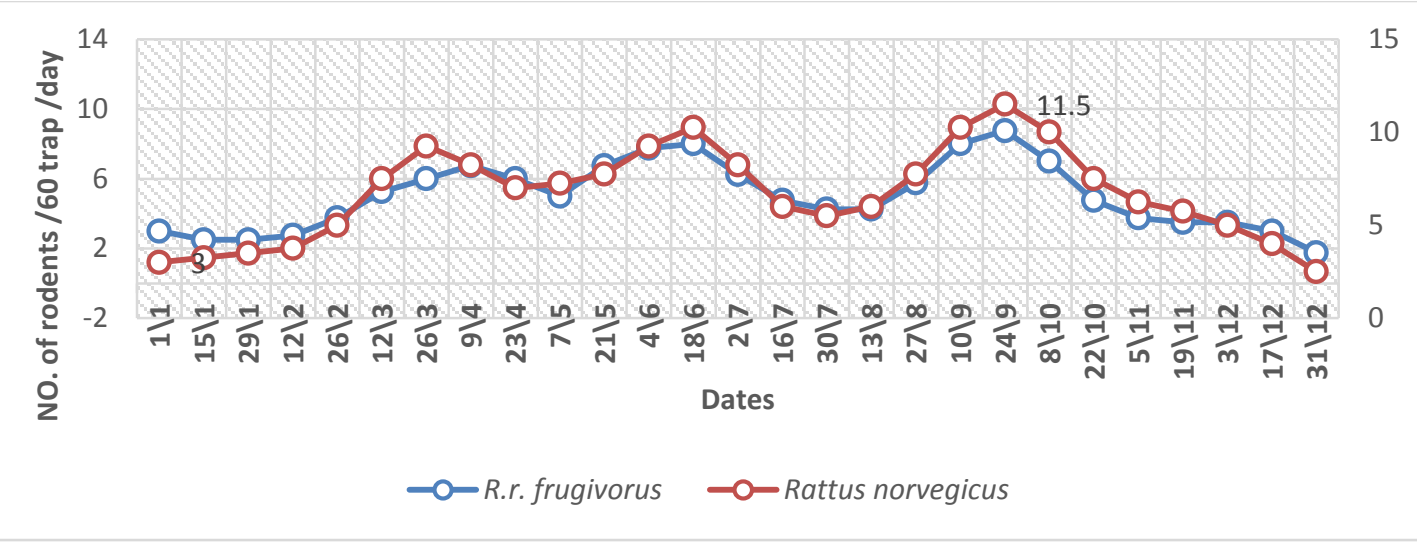

Fig (2): Population dynamic of rodents as trap index in Shosha animal production farm in Samalote district during 2018

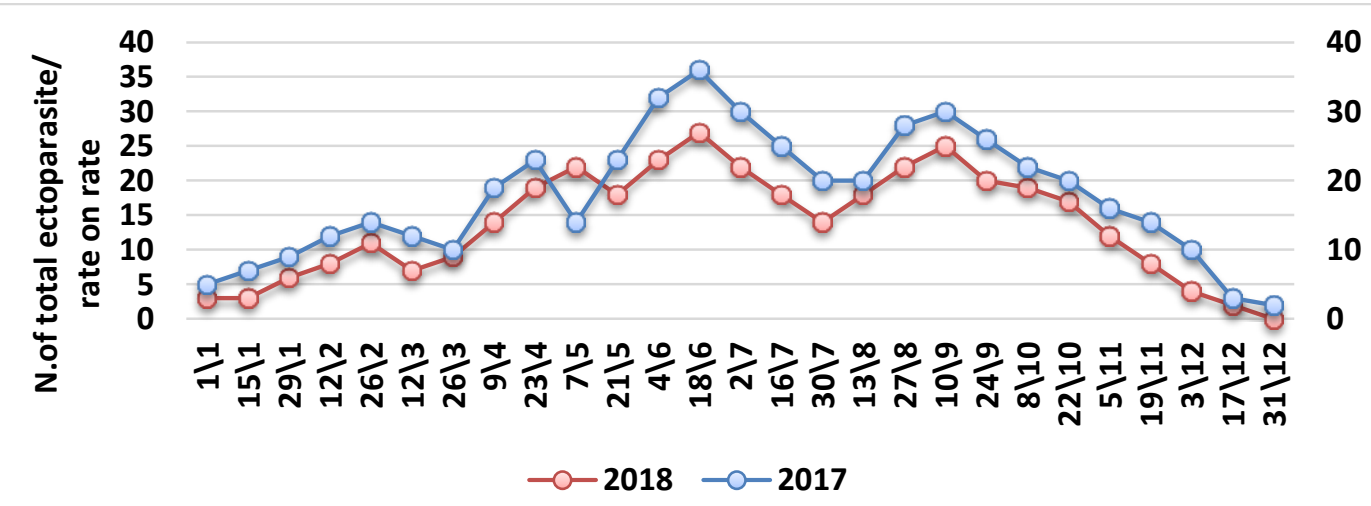

Fig (3): Population dynamic of total ecto-parasites on R. rattus frugivorus in Shosha animal production farm during $2017 \& 2018$

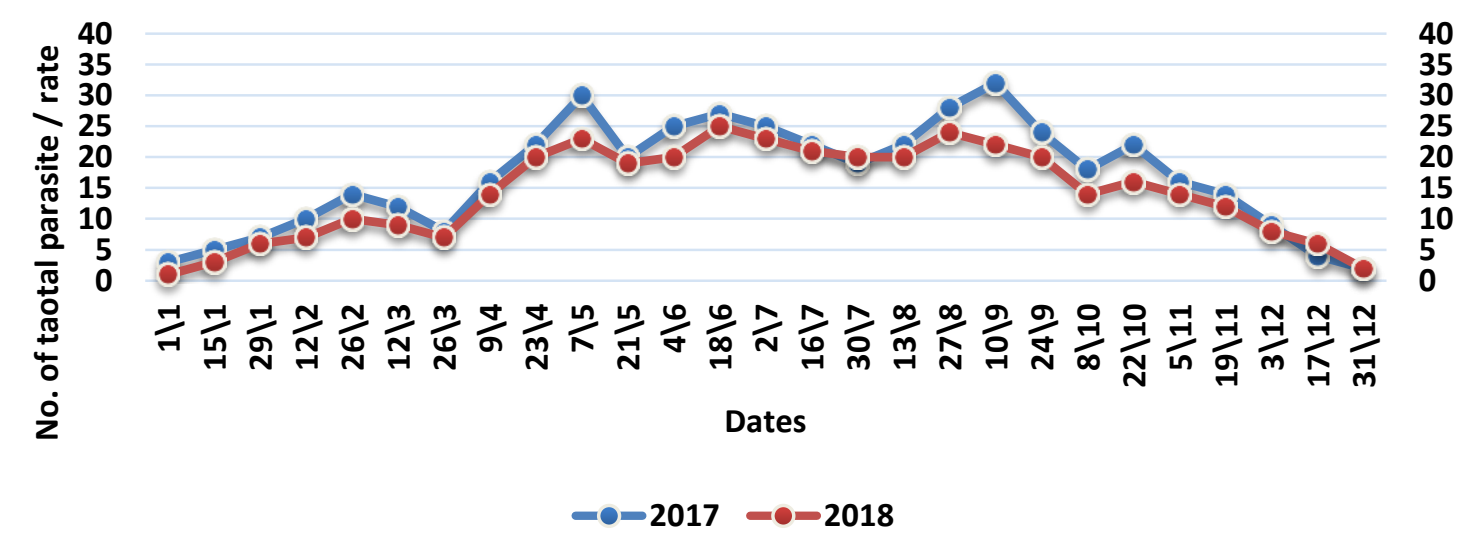

Fig (4): Population dynamic of total ecto-parasites ont Rattus norvegicus in Shosha animal production farm during $2017 \& 2018$

The effect of biweekly mean relative humidity\% on the fluctuations of both Rattus rattus frugivorous, Rattus norvegicus, and their ectoparasites separately:-

Tables $(1-4)$, showed that The calculated " $r$ " values were negatively and significantly for the effect of this factor in $1^{\text {st }}$ and nonsignificant at the two other periods of activity during 2017 and significantly negative in the $1^{\text {st }}, 3^{\text {rd }}$ and $4^{\text {th }}$ periods in 2017 for $R$. norvegicus and significantly 
negative during the first three periods of activity during 2018. The partial regression on the biweekly mean relative humidity in each period is shown in Tables (1 and 2). The tabulated figures indicated that partial regression values were negative and significant during the majority of tested periods of activity. Therefore, it could be concluded, that a drop in of $1 \%$ in the biweekly mean relative humidity increased the average population of rodents from one count to another from 0.17 and 0,142 rodents during. 2017 and from 0.0 .17 to 0.87 for $R$. rattus frugivorous. These results support that in the periods of activity the influence of the biweekly mean relative humidity was generally, within the optimal range of activity in spring and summer. However, during the winter and autumn periods, this factor was not in the optimal range. The same trend was observed with the ectoparasites associated.

The effect of biweekly maximum temperature on the fluctuations of both Rattus rattus frugivorous, Rattus norvegicus, and their ectoparasites separately: -

As shown in Tables (1 to 4), the calculated "r" values were positively significant for the effect of this factor in the $1^{\mathrm{s}}$, and $3^{\text {rd }}$ periods for both of the rodent species at both years and it was positive or negative and insignificant during the $2^{\text {nd }}$ period. The partial regression on biweekly maximum temperature indicated that partial regression values were negative and insignificant in the $2^{\text {nd }}$ period for $R$. rattus and the $2^{\text {nd }}$ and $3^{\text {rd }}$ period 2018 for $R$. norvegicus. However, during the $1^{\text {st }}$ and $2^{\text {nd }}$ periods, the calculated values were positive and significant. Therefore, it could be concluded; however, that a drop in $1 \mathrm{C}^{\circ}$ in the biweekly maximum temperature increased the average population of rodents from one count to another ranged from 0.011 to 1.54 rodents and was difrenat according to the period of activity and the species of rodent. The same trend was observed with ectoparasites.

The effect of biweekly minimum temperature on the fluctuations in the number of rodents and their ectoparasite: -

The tested weather factor was within the optimal range for rodent activity in the $2^{\text {nd }}, 3^{\text {rd }}$ periods. Statistically, the regression of any independent variable is due to a unit change in the independent factor. It was obvious that an increase of $1 \mathrm{C}^{\circ}$ in the departures of biweekly mean minimum temperature caused an increase of +2.71 rodent and -0.31 , and it ranged from positive and negative non significant effect for Rattus rattus frugivorous, Rattus norvegicus and total ectoparasite in the total population from count to another in the $1^{\text {st }}$ period, $2^{\text {nd }}, 3^{\text {rd }}$ and 5 th periods respectively. The partial regression value was positive and highly significant only at the $4^{\text {th }}$ period during 2018 for $R$. norvegicus this means that an increase of $1 \mathrm{C}^{\circ}$ in the biweekly mean minimum temperature caused significant an increase of rodents 2.71 and decrease - 0.31 rodents during the first period of activity of 2018 in the population from count to another for $R$. rattus frugivorus. The same results were observed for the total numbers of ectoparasites, their effect was not significant except the fourth period of activity of the ectopasite associated with $R$. rattus frugivorus.and only significant positive effect on the fifth period of activity 2018 for $R$. norvegicus.

\section{The combined effect of the three weather factors on the activity periods of rodents and their ectoparasites}

The combined effect of the three weather factors on the fluctuation of population activity of the two species of rodents was ranged from 78.9 to $98.03 \%$ and from 55.31 to $99.11 \%$ for $R$. rattus frugivorous $R$. norvegicus during the three periods of activity for the two species respectively through the two years of study. The simultaneous effect of the three tested weather factors on the fluctuation of population activity of rodents and their parasites were varied through periods of activity. The temperature and relative humidity were two key factors which influenced the seasonal fluctuation of rodents and ectoparasites.( Dietze, M., and Lynch, H., 2019). 
Table (1): Simple correlation cofficient $(r) \pm$ se between different factors of weather and the total number of $R$. rattus frugivorus with the partial regression (P), during (2017 and 2018 seasons).

\begin{tabular}{|c|c|c|c|c|c|c|c|}
\hline year & Period & Date & Factor & Average & $(\mathrm{r})$ & $\mathrm{P}$ & E. $v$ \\
\hline \multirow{9}{*}{ 혹 } & \multirow[t]{3}{*}{$1^{\mathrm{st}}$} & \multirow[t]{3}{*}{$1 \backslash 1$ to $7 \backslash 5$} & RH & $67.77 \pm 15.73$ & $-0.82 \pm 0.2^{* *}$ & $-0.088^{*}$ & \multirow{3}{*}{$76.77 \%$} \\
\hline & & & Max. & $24.34 \pm 4.77$ & $+0.85 \pm 0.18^{* *}$ & $+0.92 \mathrm{~ns}$ & \\
\hline & & & Min & $8.42 \pm 2.58$ & $+0.79 \pm 0.21 * *$ & $-+0.21 \mathrm{~ns}$ & \\
\hline & \multirow[t]{3}{*}{$2^{\text {nd }}$} & \multirow{3}{*}{$7 \backslash 5$ to $13 \backslash 8$} & $\mathrm{RH}$ & $42.5 \pm 8.93$ & $+0.038 \pm 0.004 \mathrm{~ns}$ & $-0.18 \mathrm{~ns}$ & \multirow{3}{*}{$85.57 \%$} \\
\hline & & & Max. & $37.73 \pm 2.9$ & $+0.56 \pm 0.41 \mathrm{~ns}$ & $-0.7 \mathrm{~ns}$ & \\
\hline & & & Min & $20.45 \pm 2.55$ & $+0.64 \pm 0.38 \mathrm{~ns}$ & $++1.4 \mathrm{~ns}$ & \\
\hline & \multirow[t]{3}{*}{$3^{\text {rd }}$} & \multirow[t]{3}{*}{1318 to $31 / 12$} & RH & $68.52 \pm 7.43$ & $-0.57 \pm 0.27 \mathrm{~ns}$ & $-+0.2 * *$ & \multirow{3}{*}{$81.85 \%$} \\
\hline & & & Max. & $28.77 \pm 6.35$ & $+0.84 \pm 0.18 * *$ & $++0.8 * *$ & \\
\hline & & & Min & $14.06 \pm 6.53$ & $+0.83 \pm 0.18^{* *}$ & $-0.49 n s$ & \\
\hline \multirow{9}{*}{$\stackrel{\infty}{\stackrel{\infty}{\sigma}}$} & \multirow[t]{3}{*}{$1^{\mathrm{st}}$} & \multirow[t]{3}{*}{$1 \backslash 1$ to $7 \backslash 5$} & RH & $66.31 \pm 12.21$ & $-0.96 \pm 0.11^{* * *}$ & $-0.11^{* * *}$ & \multirow{3}{*}{$99.11 \%$} \\
\hline & & & Max. & $25.07 \pm 3.74$ & $+0.91 \pm 0.16^{* *}$ & $+0.3 \mathrm{~ns}$ & \\
\hline & & & Min & $9.28 \pm 0.08$ & $+0.62 \pm 0.31 \mathrm{~ns}$ & $-0.31^{* *}$ & \\
\hline & \multirow[t]{3}{*}{$2^{\text {nd }}$} & \multirow[t]{3}{*}{$7 \backslash 5$ to $13 \backslash 8$} & RH & $47.96 \pm 5.9$ & $-0.79 \pm 0.26^{*}$ & $-0.21 *$ & \multirow{3}{*}{$67.30 \%$} \\
\hline & & & Max. & $36.7 \pm 1.66$ & $-0.21 \pm 0.18 \mathrm{~ns}$ & $+0.16 \mathrm{~ns}$ & \\
\hline & & & Min & $20.85 \pm 1.96$ & $+0.3 \pm 0.42 \mathrm{~ns}$ & $-0.031 \mathrm{~ns}$ & \\
\hline & \multirow[t]{3}{*}{$3^{\text {rd }}$} & \multirow[t]{3}{*}{$13 \backslash 8$ to $31 / 12$} & RH & $67.06 \pm 0.09$ & $-0.39 \pm 0.3 \mathrm{~ns}$ & $+0.005 \mathrm{~ns}$ & \multirow{3}{*}{$55.31 \%$} \\
\hline & & & Max. & $28.96 \pm 6.95$ & $+0.74 \pm 0.22 * *$ & $+0.22 *$ & \\
\hline & & & Min & $14.46 \pm 6.87$ & $+0.56 \pm 0.27 \mathrm{~ns}$ & $+0.023 \mathrm{~ns}$ & \\
\hline
\end{tabular}

Table (2): Simple correlation cofficient $(r) \pm$ se between different factors of weather and the total number of $R$. norvegicus with the partial regression (P), during (2017 and 2018 seasons).

\begin{tabular}{|c|c|c|c|c|c|c|c|}
\hline year & Period & Date & Factor & Average & (r) & $\mathrm{P}$ & E. $v$ \\
\hline \multirow{7}{*}{ 궁 } & \multirow[t]{3}{*}{$1^{\mathrm{st}}$} & $1 \backslash 1$ & RH & $67.77 \pm 15.7$ & $-0.8 \pm 0.2 * *$ & $+0.11 * * *$ & \multirow[t]{3}{*}{$90.26 \%$} \\
\hline & & \multirow[t]{2}{*}{$7 \backslash 5$} & Max. & $24.34 \pm 4.77$ & $+0.86 \pm 0.17 * *$ & $+1.53 *$ & \\
\hline & & & Min & $8.42 \pm 2.58$ & $0.74 \pm 0.23 *$ & $-0.72 n s$ & \\
\hline & \multirow[t]{3}{*}{$2^{\text {nd }}$} & \multirow{3}{*}{\begin{tabular}{|c|}
$7 \backslash 5$ \\
to $30 \backslash 7$
\end{tabular}} & RH & $42.5 \pm 8.93$ & $-0.48 \pm 0.43 \mathrm{~ns}$ & $0.28 \mathrm{~ns}$ & \multirow[t]{3}{*}{$96.25 \%$} \\
\hline & & & Max. & $37.73 \pm 2.9$ & $+0.2 \pm 0.48 \mathrm{~ns}$ & $-0.97 n s$ & \\
\hline & & & Min & $20.45 \pm 2.55$ & $+0.16 \pm 0.49 \mathrm{~ns}$ & $+1.69 *$ & \\
\hline & $3^{\text {rd }}$ & $\begin{array}{c}30 \backslash 7 \text { to } \\
31 / 12\end{array}$ & RH & $68.52 \pm 7.43$ & $-0.54 \pm 0.28 \mathrm{~ns}$ & $-0.17 * * *$ & 85.72 \\
\hline
\end{tabular}




\begin{tabular}{|c|c|c|c|c|c|c|c|}
\hline & & & Max. & $28.77 \pm 6.35$ & $+0.89 \pm 0.15 * * *$ & $+0.76^{* *}$ & \\
\hline & & & Min & $14.06 \pm 6.53$ & $+0.88 \pm 0.16^{* * *}$ & $-0.37 \mathrm{~ns}$ & \\
\hline \multirow{9}{*}{$\stackrel{\infty}{\stackrel{i}{i}}$} & \multirow[t]{3}{*}{$1^{\mathrm{st}}$} & \multirow{3}{*}{$\begin{array}{l}1 \backslash 1 \\
\text { to } \\
7 \backslash 5\end{array}$} & RH & $66.31 \pm 12.2$ & $-0.87 \pm 0.19 * *$ & $0.011 * * *$ & \multirow[t]{3}{*}{$98.003 \%$} \\
\hline & & & Max. & $25.07 \pm 3.74$ & $+0.87 \pm 0.19 * *$ & $+1.11 \mathrm{~ns}$ & \\
\hline & & & Min & $9.28 \pm 0.08$ & $+0.52 \pm 0.34 \mathrm{~ns}$ & $-0.73^{* *}$ & \\
\hline & \multirow[t]{3}{*}{$2^{\text {nd }}$} & \multirow{3}{*}{$\begin{array}{c}7 \backslash 5 \\
\text { to } 30 \backslash 7\end{array}$} & $\mathrm{RH}$ & $47.96 \pm 5.9$ & $-0.79 \pm 0.27 *$ & $-0.142 * *$ & \multirow[t]{3}{*}{$98.86 \%$} \\
\hline & & & Max. & $36.7 \pm 1.66$ & $-0.45 \pm 0.39 n s$ & $-0.51 \mathrm{~ns}$ & \\
\hline & & & Min & $20.85 \pm 1.96$ & $+0.54 \pm 0.37 \mathrm{~ns}$ & $+0.67 * *$ & \\
\hline & \multirow[t]{3}{*}{$3^{\text {rd }}$} & \multirow{3}{*}{$\begin{array}{c}30 \backslash 7 \text { to } \\
31 / 12\end{array}$} & RH & $67.06 \pm 0.09$ & $-0.38 \pm 0.3 \mathrm{~ns}$ & $+0.18 \mathrm{~ns}$ & \multirow[t]{3}{*}{$78.79 \%$} \\
\hline & & & Max. & $28.96 \pm 6.95$ & $+0.77 \pm 0.21 * *$ & $-0.85 * *$ & \\
\hline & & & Min & $14.46 \pm 6.87$ & $+0.81 \pm 0.19 * *$ & $+1.31 *$ & \\
\hline
\end{tabular}

Table (3): Simple correlation ( $r) \pm$ se between different factors of weather and the number of ecto-parasites at $R$. rattus frugivorus with the partial regression $(\mathbf{P})$.

\begin{tabular}{|c|c|c|c|c|c|c|c|}
\hline year & $\begin{array}{c}\text { Period of } \\
\text { activity }\end{array}$ & Date & Factor & Average & $\begin{array}{c}\text { Simple } \\
\text { correlation }\end{array}$ & $\begin{array}{c}\text { Partial } \\
\text { regression }\end{array}$ & $\begin{array}{r}\text { Explained } \\
\text { variance }\end{array}$ \\
\hline \multirow{12}{*}{ 동 } & \multirow[t]{3}{*}{$1^{\text {st }}$} & \multirow{3}{*}{$\begin{array}{c}1 / 1 \\
\text { to } \\
2613\end{array}$} & RH\% & $76.14 \pm 9.18$ & $-0.38 \pm 0.41 \mathrm{~ns}$ & $+0.16 \mathrm{~ns}$ & \multirow[t]{3}{*}{$90.8 \%$} \\
\hline & & & Max. & $21.72 \pm 2.69$ & $+0.58 \pm 0.36 \mathrm{~ns}$ & $+2.56^{*}$ & \\
\hline & & & Min & $5.86 \pm 2.18$ & $+0.14 \pm 0.44 \mathrm{~ns}$ & $-1.93 \mathrm{~ns}$ & \\
\hline & \multirow[t]{3}{*}{$2^{\text {nd }}$} & \multirow{3}{*}{$\begin{array}{c}2613 \\
\text { To } \\
7 \backslash 5\end{array}$} & RH\% & $48.25 \pm 6.62$ & $+0.71 \pm 0.7 \mathrm{~ns}$ & $0.62 \mathrm{~ns}$ & \multirow[t]{3}{*}{$99.1 \%$} \\
\hline & & & Max. & $30.45 \pm 0.68$ & $-0.71 \pm 0.7 \mathrm{~ns}$ & $-3.3 \mathrm{~ns}$ & \\
\hline & & & Min & $14.9 \pm 1.37$ & $-0.096 \pm 0.9 \mathrm{~ns}$ & $+3.6 \mathrm{~ns}$ & \\
\hline & \multirow[t]{3}{*}{$3^{\text {rd }}$} & \multirow{3}{*}{$\begin{array}{c}7 \backslash 5 \\
\text { to } \\
30 \backslash 7\end{array}$} & RH\% & $42.58 \pm 8.96$ & $-0.60 \pm 0.39 n s$ & $-0.87 *$ & \multirow[t]{3}{*}{$95.31 \%$} \\
\hline & & & Max. & $37.73 \pm 2.94$ & $+0.25 \pm 0.48 \mathrm{~ns}$ & $-2.22 n s$ & \\
\hline & & & Min & $20.45 \pm 2.55$ & $+0.11 \pm 0.49 \mathrm{~ns}$ & $+4.16 \mathrm{~ns}$ & \\
\hline & \multirow[t]{3}{*}{$4^{\text {th }}$} & \multirow{3}{*}{$\begin{array}{c}13 \backslash 8 \\
\text { to } \\
31 \backslash 12\end{array}$} & RH\% & $68.47 \pm 7.36$ & $+0.44 \pm 0.26 \mathrm{~ns}$ & $-0.17 *$ & \multirow[t]{3}{*}{$78.67 \%$} \\
\hline & & & Max. & $28.77 \pm 6.35$ & $+0.88 \pm 0.12 \mathrm{~ns}$ & $-1.27 * *$ & \\
\hline & & & Min & $14.4 \pm 6.17$ & $+0.86 \pm 0.16^{* *}$ & $-0.05 n s$ & \\
\hline \multirow[t]{8}{*}{2018} & \multirow[t]{3}{*}{$1^{\text {st }}$} & \multirow{3}{*}{$\begin{array}{c}1 / 1 \\
\text { to } \\
12 \backslash 3\end{array}$} & RH\% & $73.11 \pm 9.88$ & $-0.76 \pm 0.28$ & $-0.32 *$ & \multirow[t]{3}{*}{$86.03 \%$} \\
\hline & & & Max. & $23.18 \pm 3.83$ & $+0.84 \pm 0.24 *$ & $-0.9 n s$ & \\
\hline & & & Min & $7.98 \pm 2.96$ & $+0.91 \pm 0.17 * *$ & $+1.11 \mathrm{~ns}$ & \\
\hline & \multirow[t]{3}{*}{$2^{\text {nd }}$} & \multirow{3}{*}{$\begin{array}{c}26 \backslash 3 \\
\text { to } \\
21 \backslash 5\end{array}$} & RH\% & $49.66 \pm 6.21$ & $-0.89 \pm 0.44 \mathrm{~ns}$ & $+0.21 \mathrm{~ns}$ & \multirow[t]{3}{*}{$100 \%$} \\
\hline & & & Max. & $30.2 \pm 3.06$ & $+0.84 \pm 0.53 \mathrm{~ns}$ & $-1.1 \mathrm{~ns}$ & \\
\hline & & & Min & $13.77 \pm 3.54$ & $+0.96 \pm 0.26 \mathrm{~ns}$ & $+2.19 \mathrm{~ns}$ & \\
\hline & \multirow[t]{2}{*}{$3^{\text {rd }}$} & \multirow{2}{*}{$\begin{array}{c}21 \backslash 5 \\
\text { to }\end{array}$} & RH\% & $48.25 \pm 6.44$ & $-0.64 \pm 0.38 \mathrm{~ns}$ & $-0.94 *$ & \multirow[t]{2}{*}{99.15} \\
\hline & & & Max. & $37.27 \pm 2.94$ & $+0.98 \pm 0.09 * *$ & $-4.7 n s$ & \\
\hline
\end{tabular}




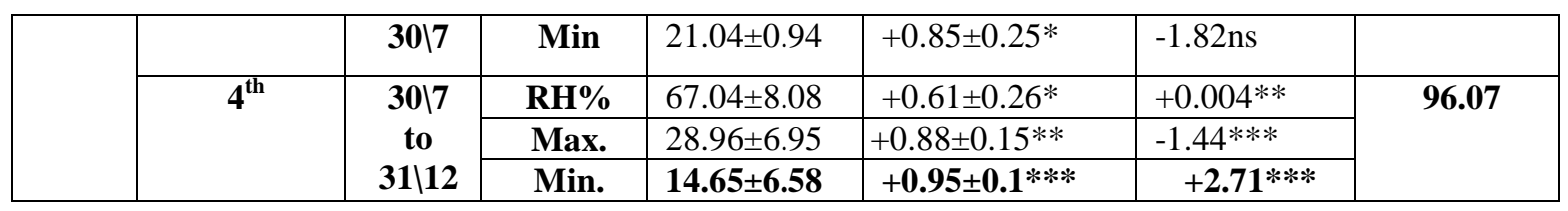

Table (4): Simple correlation ( $r) \pm$ se between different factors of weather and total number of ecto-parasites at Rattus norvegicus with the partial regression (P), during (2017 and 2018 seasons).

\begin{tabular}{|c|c|c|c|c|c|c|c|}
\hline year & $\begin{array}{l}\text { Period of } \\
\text { activity }\end{array}$ & Date & Factor & Average & $\begin{array}{c}\text { Simple } \\
\text { correlation }\end{array}$ & $\begin{array}{l}\text { Partial } \\
\text { regression }\end{array}$ & $\begin{array}{c}\text { Explained } \\
\text { variance }\end{array}$ \\
\hline \multirow{15}{*}{ 홍 } & \multirow[t]{3}{*}{$1^{\text {st }}$} & \multirow[t]{3}{*}{$1 / 1$ to $26 \backslash 3$} & RH & $76.14 \pm 9.18$ & $+0.404 \pm 0.41 \mathrm{~ns}$ & $+0.173 \mathrm{~ns}$ & \multirow[t]{3}{*}{$78.4 \%$} \\
\hline & & & Max. & $21.72 \pm 2.69$ & $+0.57 \pm 0.36 \mathrm{~ns}$ & $2.9 \mathrm{~ns}+$ & \\
\hline & & & Min & $5.86 \pm 2.18$ & $+0.18 \pm 0.44 \mathrm{~ns}$ & $-2.13 n s$ & \\
\hline & \multirow[t]{3}{*}{$2^{\text {nd }}$} & \multirow[t]{3}{*}{$26 \backslash 3$ to $21 \backslash 5$} & RH & $48.1 \pm 10.24$ & $-0.91 \pm 0.24 *$ & $-0.82 n s$ & \multirow[t]{3}{*}{95.71} \\
\hline & & & Max. & $30.15 \pm 2.6$ & $+0.89 \pm 0.25^{*}$ & $-0.16 n s$ & \\
\hline & & & Min & $14.05 \pm 2.7$ & $+0.93 \pm 0.20 *$ & $+3.1 \mathrm{~ns}$ & \\
\hline & \multirow[t]{3}{*}{$3^{\text {rd }}$} & \multirow[t]{3}{*}{$21 \backslash 5$ to $30 \backslash 7$} & $\mathrm{RH}$ & $42.58 \pm 8.96$ & $-0.93 \pm 0.17 * *$ & $-0.44 *$ & \multirow[t]{3}{*}{$99.1 \%$} \\
\hline & & & Max. & $37.73 \pm 2.94$ & $-0.20 \pm 0.40 \mathrm{~ns}$ & $-0.71 \mathrm{~ns}$ & \\
\hline & & & Min & $20.45 \pm 2.55$ & $-0.46 \pm 0.44 n s$ & $1.12 \mathrm{~ns}$ & \\
\hline & \multirow[t]{3}{*}{$4^{\text {th }}$} & \multirow[t]{3}{*}{$30 \backslash 7$ to $8 \backslash 10$} & $\mathrm{RH}$ & $62.35 \pm 2.88$ & $+0.24 \pm 0.56 \mathrm{~ns}$ & $-3.71 \mathrm{~ns}$ & \multirow[t]{3}{*}{76.33} \\
\hline & & & Max. & $35.46 \pm 1.83$ & $-0.54 \pm 0.48 n s$ & $-18.5 n s$ & \\
\hline & & & Min & $21.14 \pm 2.35$ & $-0.32 \pm 0.54 n s$ & $+15.56 \mathrm{~ns}$ & \\
\hline & \multirow[t]{3}{*}{$5^{\text {th }}$} & \multirow{3}{*}{$\begin{array}{l}8 \backslash 10 \text { to } \\
31 \backslash 12\end{array}$} & RH & $71.55 \pm 7.54$ & $-0.26 \pm 0.43 n s$ & $+0.13^{*}$ & \multirow[t]{3}{*}{98.55} \\
\hline & & & Max. & $25.22 \pm 5.05$ & $+0.86 \pm 0.22 * *$ & $-0.89 * *$ & \\
\hline & & & Min & $10.18 \pm 4.42$ & $+0.98 \pm .08 * * *$ & $0.64^{*}$ & \\
\hline \multirow{15}{*}{$\stackrel{\infty}{\infty}$} & \multirow[t]{3}{*}{$1^{\mathrm{st}}$} & \multirow[t]{3}{*}{$1 / 1$ to $26 \backslash 3$} & RH & $73.11 \pm 9.88$ & $-0.75 \pm 0.29 n s$ & $+1.02 *$ & \multirow{3}{*}{$86.17 \%$} \\
\hline & & & Max. & $23.18 \pm 3.83$ & $+0.83 \pm 0.24 *$ & $+3.6 \mathrm{~ns}$ & \\
\hline & & & Min & $7.98 \pm 2.96$ & $+0.86 \pm 0.22 *$ & $-0.53 n s$ & \\
\hline & \multirow[t]{3}{*}{$2^{\text {nd }}$} & \multirow[t]{3}{*}{$26 \backslash 3$ to $21 \backslash 5$} & RH & $49.66 \pm 6.21$ & $-0.79 \pm 0.35 n s$ & $-0.53 \mathrm{~ns}$ & \multirow[t]{3}{*}{97.23} \\
\hline & & & Max. & $31.36 \pm 4.47$ & $+0.58 \pm 0.47 \mathrm{~ns}$ & $-0.27 n s$ & \\
\hline & & & Min & $14.21 \pm 2.76$ & $+0.76 \pm 0.37 \mathrm{~ns}$ & $+3.3 \mathrm{~ns}$ & \\
\hline & \multirow[t]{3}{*}{$3^{\text {rd }}$} & \multirow[t]{3}{*}{$21 \backslash 5$ to $30 \backslash 7$} & $\mathrm{RH}$ & $48.25 \pm 6.44$ & $-0.13 \pm 0.49 n s$ & $+0.16 \mathrm{~ns}$ & \multirow[t]{3}{*}{$83.94 \%$} \\
\hline & & & Max. & $37.27 \pm 2.94$ & $-0.82 \pm 0.25^{*}$ & $-2.79 n s$ & \\
\hline & & & Min & $21.04 \pm 0.94$ & $+0.74 \pm 0.33 \mathrm{~ns}$ & $-0.78 n s$ & \\
\hline & \multirow[t]{3}{*}{$4^{\text {th }}$} & \multirow[t]{3}{*}{$30 \backslash 7$ to $8 \backslash 10$} & RH\% & $60.3 \pm 2.98$ & $+0.29 \pm 0.55 \mathrm{~ns}$ & $2.84 \mathrm{~ns}$ & \multirow[t]{3}{*}{91.13} \\
\hline & & & Max. & $35.86 \pm 2.12$ & $-0.27 \pm 0.55 n s$ & $3.11 \mathrm{~ns}$ & \\
\hline & & & Min. & $21.21 \pm 0.70$ & $+0.40 \pm 0.52 \mathrm{~ns}$ & $3.46 \mathrm{~ns}$ & \\
\hline & \multirow[t]{3}{*}{$5^{\text {th }}$} & $8 \backslash 10$ to & RH\% & $70.57 \pm 8.1$ & $-0.13 \pm 0.44 n s$ & $-.08 \mathrm{~ns}$ & 94.26 \\
\hline & & $31 \backslash 12$ & Max. & $25.40 \pm 6.2$ & $+0.95 \pm 0.13 * * *$ & $1.94 * *$ & \\
\hline & & & Min. & $10.43 \pm 5.41$ & $+0.90 \pm 0.19 * *$ & $-1.38 n s$ & \\
\hline
\end{tabular}




\section{REFERENCES}

Corominas, I.T. (2004): Distribution, population dynamicsand habitat selection of small mammals in Mediterranean environments: the role of climate, vegetation structure, and predation risk. Ph.D. Dissertation, University of Barcelona, Barcelona,pp.178

EL Roby, A.S.M, Hassan, H.M.; Eshbah, M.H., and Abd El Hakeem, Arwa, A.(2021):Survey of rodents and their ectoparasites at some animal farms in Minia Governorate . Journal of modern research ( accepted)

Evans, G.O. (1992): Principles of Acarology. C.A.B. International Walling Ford. 522pp.

Dietze, M., Lynch, H., 2019. Forecasting a bright future for ecology. Front. Ecol. Environ. 17, 3. https://doi.org/10.1002/fee.1994

Hegab, A. M., S. A. A. Ismail and S. A. A. El-Massry (2006). Survey, morphological studies and ectoparasites associated with some commensal rat species at Sharkia Governorate. Egypt. J. of Appl. Sci., 21 (5): 340-349.

Hosny, M. M. (1955). Notes on the effect of Some Secondary Environmental Conditions on the activity of Nocturnal Macro_ Lepidoptera. Bull. Sec. Entomol. d'Egypt. 39:297-314 pp.

Hughes, A. M. (1961): The mites of stored food. Tech. Bull. Minist. Agric. Fisheries and Food.9:1-379.

Hughes, A. M. (1976): The mites of stored food and houses. Tech. Bull. Minist. Agric. London. 9:1-287.

Hussien S. S. M. (1991). Ecological studies and control of certain rodents in Beni suef Governorate. M. Sc. Thesis, Fac. of Agric., Cairo Univ.

Hussein, S.M., Omar Aza H., EL Ghariani, (2014) Studies on the population dynamics of the red scale Aunidiella aurantii mask in El Beida region during 2012-2013 seasons 2nd conference of plant Protection Society of libya, EL Beida 1:236

Jacob, J. and Tkadlee (2008). The response of small rodents to mani pulations of vegetation height in agro-ecosystems. Integrative Zoology, 3,3-10.

Karg, W. (1971): Acari (Acarina), Miben, Unterordung Analinochaeta (Parasitiformes). Die freilebendeen Gamasina (Gamasides). Jena teil 59: 475pp.

Krantz, G. M. (1978): A manual of Acarology $2^{\text {nd }}$ edn. Oregon State University, Corvallis, Oregon: 509 pp.

Krebs CJ (2013). Population Fluctuations in Rodents. University of Chicago Press, Chicago

Nicolas, V. and Colyn, M. (2006): Relative efficiency of the three types of small mammal traps in an African rainforest. Belg. J. Zool., 136: 107-111.

Radchuk, V., Ims, R.A., Andreassen, H.P., 2016. From individuals to population cycles: the role of extrinsic and intrinsic factors in rodent populations. Ecology 97, 720-732.

Rizk, A.M.; Eisa, Y. A.E. and Abdel-Azeem, M.I. (2017): Survey of rodent species at three habitats and control it by use change base carrier of Zinc Phosphide bait technique in Sohag Governorate. Egyptian Academic Journal of Biological Sciences, B. Zoology, 9(1): $33-42$ 
Rizk, G.A. ; Sheta I.B. and Hussein S.M. (1978): Some aspects of the population activity of Aonidiella aurantii (Mask.) in relation to weather factors in Middle Egypt. Proceeding of 4th conference pest control NRC, Cairo Vol. I : 62-71

Salit, A. M., Helal, T. Y., Ali, M.A., Abdel - Gawad, K. H. and Arafa, M. S. (1982).Composition of the rodent species in newly reclaimed semi-desert area comparing with cultivated land. Assiut Journal of Agric. Sciences, 13(2): 53-62

Taylor, K.D., (1972). Rodent problems in tropical agriculture. Int. J. Pest Manag. 18, 81-88.

Wilson, D.E., Reeder, D.M., 2005. Mammal Species of the World: A Taxonomic and Geographic Reference. Johns Hopkins University Press, Baltimore, USA

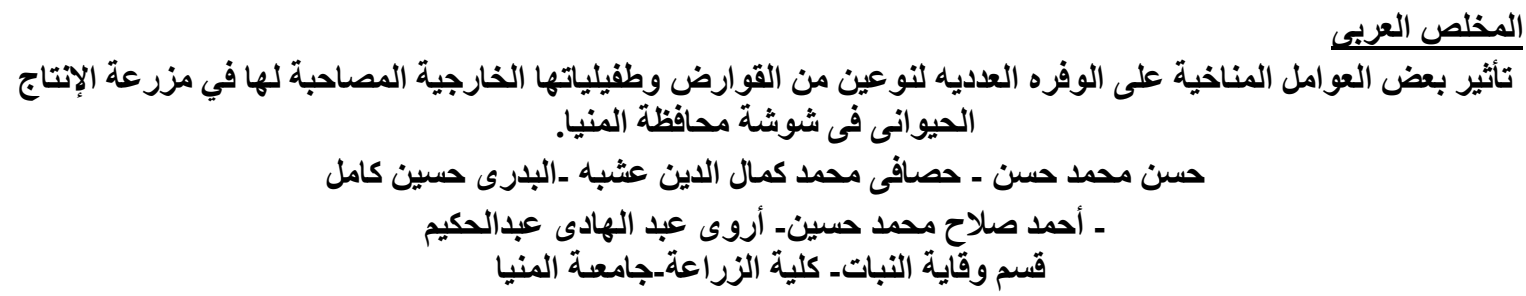

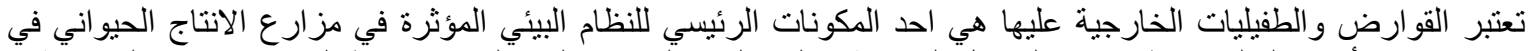

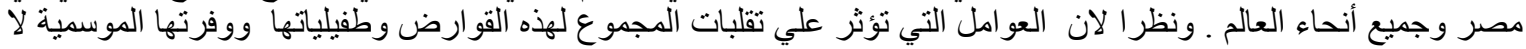

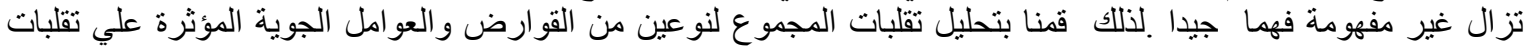

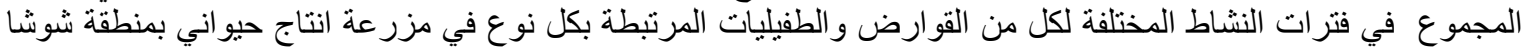
بمحافظة المنيا خلال موسي في النياط المي 2017 و 2018.

و عند تحليل التقلبات الموسمية خلال فترات نشاط لكلا من الجرذ المنسلق ذو البطن البيضاء والجرذ الجناء النرويجى والطفيليات

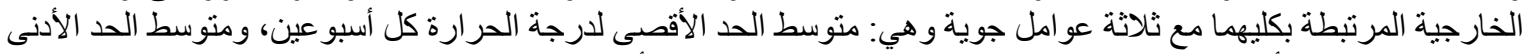

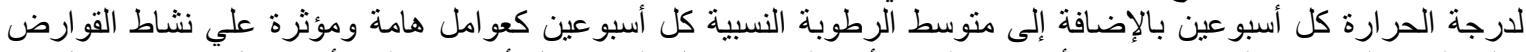

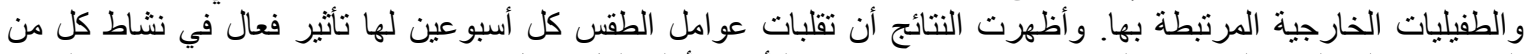

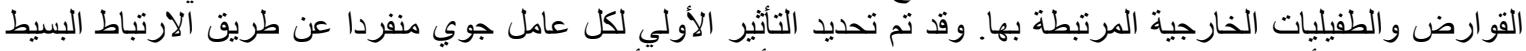

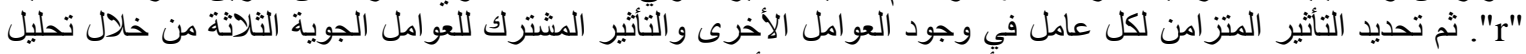

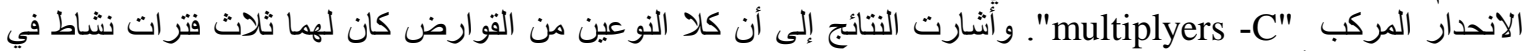

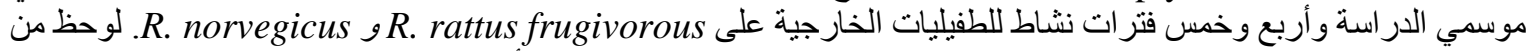

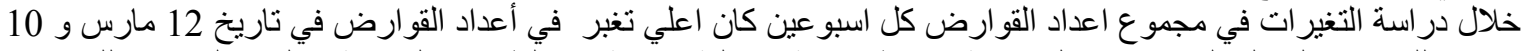

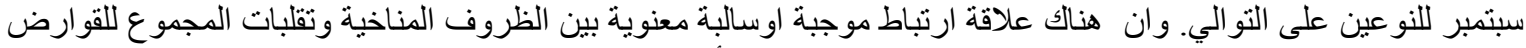

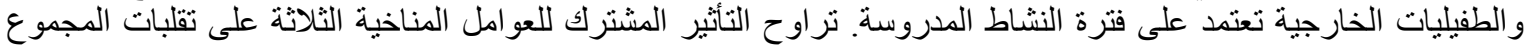
R. rattus frugivorous R. norvegicus النوعي القوارض من 78.9 إلى

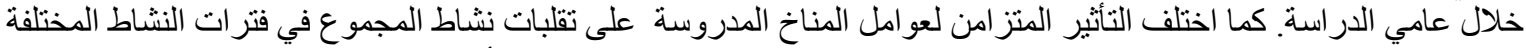

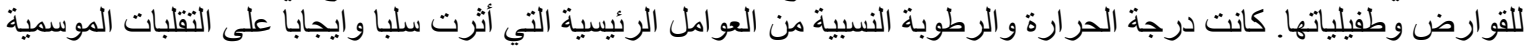
للقو ارض و الطفيليات الخارجية. 